Crop Breeding and Applied Biotechnology 15: 87-93, 2015

Brazilian Society of Plant Breeding. Printed in Brazil

\title{
ARTICLE
}

http://dx.doi.org/10.1590/1984-70332015v15n2a16

\section{Reaction and colonization of common bean genotypes by Curtobacterium flaccumfaciens pv. flaccumfaciens}

Antonio Carlos Maringoni ${ }^{1 *}$, Mariane Sayuri Ishiszuka ${ }^{1}$, Amanda Portes da Silva ${ }^{1}$, José Marcelo Soman ${ }^{1}$, Mônika Fecury Moura $^{1}$, Ricardo Lima dos Santos ${ }^{1}$, Tadeu Antônio Fernandes da Silva Júnior ${ }^{1}$, Alisson Fernando Chiorato ${ }^{2}$, Sérgio Augusto Morais Carbonell ${ }^{2}$ and Nelson da Silva Fonseca Júnior ${ }^{3}$

Received 20 May 2014

Accepted 07 November 2014

\begin{abstract}
Bacterial wilt is one of the main diseases of common beans and the use of cultivars with some level of resistance is fundamental for an adequate disease management. The reaction of 54 common bean genotypes to Curtobacterium flaccumfaciens $p v$. flaccumfaciens (Cff) was evaluated, and the colonization of cultivars and obstruction of primary xylem vessels at the petiole base were assessed. In greenhouse and laboratory tests, resistance was detected in the cultivars IAC Diplomata, IAC Alvorada, IAC Imperador, IPR Corujinha, and IPR Tangará, and in the lines P5-4-4-1 and C4-5-4-1-2. The Cff colonization rate was also slower in the resistant cultivars (IAC Diplomata, IAC Carioca Tybatã, and IAC Carioca Pyatã) and the percentage of obstruction of primary xylem vessels at the petiole base lower than in the susceptible cultivars (IAC Carioca and Pérola).
\end{abstract}

Keywords: Bacterial wilt, cultivars resistance, Phaseolus vulgaris, xylem.

\section{INTRODUCTION}

Brazil is one of the world's leading common bean producers and consumers, with a harvest of almost three million tons in 2012, in the main producing states of Paraná, Minas Gerais, São Paulo and Goiás (Agrianual 2013). Bacterial diseases are among the yield-limiting factors of the crop in the country, particularly bacterial wilt. This disease is caused by Curtobacterium flaccumfaciens pv. Alaccumfaciens (Cff), and was first described by Hedges (1922) in the USA. Currently, the disease has already been detected in several countries (EPPO 2011) and Brazilian states (Valentini et al. 2010). Bacterial wilt colonizes the xylem vessels of the affected plants, leading to disruption and degradation of the primary xylem. Infected plants show symptoms of wilting leaves, which later evolve to withering and death (Dinesen 1978). Yield losses in susceptible cultivars can be close to 50\% (Miranda Filho 2006).

Bacterial wilt is controlled by preventive measures, e.g., by using healthy seeds, incorporation of crop bean residues into the soil, crop rotation with non-host species, and by using cultivars with some level of resistance (Huang et al. 2009, Valentini et al. 2010).

A number of studies identified Cff-resistant common bean genotypes in Brazil. According to Maringoni (2002), high resistance levels were observed in the cultivars IAC Carioca Akytã, IAC Carioca Aruã, and IAC Carioca Pyatã. Souza et al. (2006) evaluated 333 accessions of the common bean germplasm bank of the Agronomic Institute of Campinas (IAC), and identified 29 as highly resistant to the bacterium, including cultivars IAPAR 31 and IAC Carioca Tybatã. Rava et al. (2004) found high levels of Cff-resistance in the common bean accessions Mulatinho, FeijãoBranco, Desconhecido, Amarelinho, Enxofre/Amarelo, Coquinho Enxofre, Jalinho, Amarelo Arroxeado, Rapezão, Feijão Mourinho, Feijão Baetão, and Vermelho 1 Epamig, among a total of 333 accessions of Embrapa Rice and Beans. According to Theodoro and Maringoni (2006), the cultivars Mouro Pirituba and Vagem Amarela have satisfactory levels of Cff-resistance, and Valentini et al. (2011b) identified a certain level of resistance in the common bean accession BAF 122, and in the cultivars IAC Carioca Akytã, IAC

\footnotetext{
${ }^{1}$ UNESP, Faculdade de Ciências Agronômicas (FCA), Departamento de Proteção Vegetal, R. José Barbosa de Barros, 1780, 18.601-307, Botucatu, SP, Brazil. *E-mail: maringoni@fca.unesp.br

${ }^{2}$ Instituto Agronômico de Campinas (IAC), Av. Barão de Itapura, 1481, CP 28, 13.012-970, Campinas, SP, Brazil

${ }^{3}$ Instituto Agronômico do Paraná (IAPAR), Rod. Celso Garcia Cid, km 375, 86.047-902, Londrina, PR, Brazil
} 
Carioca Aruã, IAC Carioca Pyatã, and IAC Carioca Tybatã, whose resistance reactions were found to be as described by Maringoni (2002) and Souza et al. (2006).

In these studies, the plants were inoculated by puncturing the stem, which, according to Krause et al. (2009), is more satisfactory than inoculation by injuries at the seed hilum or cutting seedling roots to evaluate the Cff-resistance reaction of common bean plants.

Investigating the type of resistance of common bean to Cff, Valentini et al. (2011a) studied several generations derived from crosses of IAC Carioca Aruã x SCS Guará and IAC Carioca Pyatã x Pérola and found that it is controlled by genes with an additive effect, involving more than three genes, which are typical characteristics of horizontal resistance (Nelson 1978). Studies by Maringoni (2002) and Souza et al. (2006) reported a smaller amount of Cff cells in xylem vessels of resistant than of susceptible common bean genotypes, as well as a characteristic of horizontal resistance, in which defense mechanisms of the host are involved, restricting its colonization by the pathogen (Bergamin Filho et al. 1984).

This study evaluated the response behavior of 54 bean genotypes obtained from the Agronomic Institute of Campinas (IAC) and the Agronomic Institute of Paraná (IAPAR) to a Cff isolate, as well as the colonization of resistant and susceptible cultivars and obstruction of primary xylem vessels at the petiole base of inoculated plants.

\section{MATERIAL AND METHODS}

\section{Evaluation of the response behavior of common bean genotypes to $\mathbf{C f f}$}

Four separate greenhouse trials were conducted to evaluate the response behavior of common bean cultivars and lines obtained from IAC and IAPAR to Cff. The trials 1 and 2 tested 19 genotypes (IAC Carioca, IAC Carioca Alvorada, IAC Carioca Akytã, IAC CariocaAruã, IAC Carioca Diplomata, IAC Carioca Harmonia, IAC Carioca Pyatã, IAC Carioca Tybatã, IAC Una, IAC Imperador P $5-4-4-1$, C $4-5-4-1-2$, C $4-8-1-1$, C $2-1$ $-6-1-1$, C $2-3-1-1-2$, C $2-1-6-1$, PR $11-3$ $-5-1$, PR $14-2-3-2$, PR $11-6-4-1-2$, and GEN C $2-1-3$ ); trial 3 tested 31 genotypes (IAC Carioca, IAC Carioca Alvorada, IAC Carioca Diplomata, BRS Campeiro, BRS Esplendor, BRS Estilo, BRS Pontal, BRS Requinte, BRS Supremo, BRS Valente, Diamante Negro, FT Nativo, FT Soberano, IAPAR 31, IAPAR 44, IAPAR 81, IPR Corujinha, IAPAR Siriri, PR Chopim, IPR Gralha, IPR Graúna, IPR Juriti, IPR Saracura, IPR Tangará, IPR
Tiziu, IPR Uirapuru, IPR 139, SEL-2, Rio Tibagi, Rubi, and Xamego); and in trial 4 the same genotypes as in the third trial were evaluated, with exception of BRS Valente, IPR Chopim, IPR Saracura, Diamante Negro, and FT Soberano, and the inclusion of BRS Supremo, Carioca Garça, Garça Radiante, IPR Tuiuiu, IPR Campos Gerais, RCP 1-31, and Mult 05, with a total of 33 genotypes.

Seeds were germinated on Germ-test paper and three seedlings transferred to $2 \mathrm{~L}$ pots with autoclaved substrate (a mixture of soil, cured corral manure and washed sand at a ratio of $1: 1: 1$ plus $0.6 \mathrm{~kg}$ ammonium sulfate, $1.7 \mathrm{~kg}$ superphosphate, $0.6 \mathrm{~kg}$ potassium chloride and $0.8 \mathrm{~kg}$ dolomitic lime per $\mathrm{m}^{3}$ of mixture). The seedlings were inoculated nine days after seed emergence (DAE) by puncturing the stems (Maringoni 2002) with isolate Feij-2634 (Laboratory of Plant Bacteriology, FCA, UNESP, Botucatu, SP). The isolate was grown on nutrient agar (Merck, Darmstadt, Germany) with $10 \mathrm{~g} \mathrm{~L}^{-1}$ sucrose (JT Baker®, USA) (NSA) $\left(28^{\circ} \mathrm{C} / 48 \mathrm{~h}\right)$. The four trials were arranged in a randomized block design with four replications, where each plot consisted ofone pot with three plants. Plants of cv. Pérola were punctured with a needle dipped in distilled water (negative control) and isolate Feij-2634 (positive control).

The plants were maintained in a greenhouse (temperature: $22 / 32{ }^{\circ} \mathrm{C}$; relative humidity: $80 / 90 \%$ ) and disease symptoms assessed in a first trial at 7, 14, 21, and 28 days after inoculation (DAI), second trial at 14, 21, 28, and 35 DAI, third trial at 10, 17, 24, and $32 \mathrm{DAI}$ and fourth trial at 12, 18, 25 and 32 DAI, in which grades were assigned on a 0-9 scale, as suggested by Maringoni (2002). With the resulting severity values, the area under the disease progress curve (AUDPC) was determined, as described by Campbell and Madden (1990), in which the values were subjected to analysis of variance and the means compared by the Scott-Knott test $(p<0.05)$. For the classification of the reaction to bacterial wilt, the common bean genotypes were separated into three groups: resistant (R) (AUDPC less than 50\% of cv. Pérola), moderately resistant (MR) (AUDPC value between $50-60 \%$ of cv. Pérola) and susceptible (S) (AACPC value above $60 \%$ of cv. Pérola).

\section{Monitoring of colonization and quantification of obstruction of primary xylem vessels of bean cultivars by $\mathrm{Cff}$}

Seeds of the cultivars IAC Carioca Tybatã, IAC Carioca Pyatã, IAC Carioca Diplomata, Pérola, and IAC Carioca were pre-germinated on Germ-test paper and the seedlings transferred to 2-L pots containing autoclaved substrate. Tenday-old plants were inoculated with isolate Feij-2634, as 
described by Maringoni (2002). Plants of cv. Pérola were punctured with a needle dipped in distilled water represented the negative control. Four plants per genotype (one per replication) were sampled 5, 15 and 25 DAI. Fragments of the base petioles were collected from the primary leaf and the first, second and/or third trifoliate leaf per plant.

Petiole samples were sterilized in $70 \%$ alcohol $(30$ $\mathrm{sec}), 2 \%$ sodium hypochlorite $(1 \mathrm{~min})$, washed, ground in sterile distilled water, plated on semi-selective medium for Cff (Maringoni et al. 2006), and incubated at $28{ }^{\circ} \mathrm{C}$ for $96 \mathrm{~h}$. Typical Cff colonies were purified in NSA medium with $70 \mathrm{~g} \mathrm{~L}^{-1} \mathrm{NaCl}$, analyzed by differential Gram staining and solubility in $2 \% \mathrm{KOH}$, and stored at $-80^{\circ} \mathrm{C}$ in nutrient broth medium ( $30 \%$ glycerol). The pathogenicity of the isolates was confirmed in cv. Pérola plants (Maringoni et al. 2006). The experimental design consisted of randomized complete blocks with four replications, represented by one pot with three plants.

To measure the obstruction of the primary xylem vessels, four plants per genotype were sampled $25 \mathrm{DAI}$ and fragments of the petiole bases were collected from the first, second and third trifoliate leaf of each plant. The fragments were fixed in AAF (ethanol 70\% - $90 \mathrm{ml}$; glacial acetic acid - $5 \mathrm{ml}$; and formaldehyde - $5 \mathrm{ml}$ ) for $48 \mathrm{~h}$, and maintained in ethanol 70\% until embedment (Queiroz-Voltan et al. 2005). The fragments were dehydrated in alcohol series, embedded in historesin Technovit 7100® (Heraeus Kulzer, Wehrheim, Germany), as indicated by the manufacturer. The blocks were cut (thickness $8 \mu \mathrm{m}$ ) in a manual rotary microtome (Leica, model RM 2155), fixed on microscope slides, and then stained with toluidine blue (toluidine blue - $0.01 \mathrm{~g}$; $0.1 \mathrm{M}$ sodium acetate buffer $-100 \mathrm{ml}$; $\mathrm{pH}$ 3.8) for $5 \mathrm{~min}$, and washed in tap water ( $5 \mathrm{~min}$.). The slides were dried and mounted with Entellan ${ }^{\circledR}$ (Merck).

Approximately 100 primary xylem vessels per sample were evaluated under a binocular microscope (Leica, model DM 500) with a camera. The percentage of blocked vessels was calculated, the data were subjected to analysis of variance and the means compared by the Scott-Knott test $(\mathrm{p}<0.05)$.

\section{RESULTS AND DISCUSSION}

Several studies in Brazil have consistently shown the reaction of Cff-resistance or high levels of Cff-resistance in the cultivars IAC Carioca Aruã, IAC Carioca Pyatã and IAC Carioca Akytã (Maringoni 2002, Souza et al. 2006, Camara et al. 2009, Valentini et al. 2011a, b), IAC Carioca Tybatã (Souza et al. 2006, Camara et al. 2009, Krause et al. 2009, Valentini et al. 2011a), and IAPAR 31 (Souza et al. 2006,

Table 1. Determination of the area under the disease progress curve (AUDPC) and reaction of common bean genotypes to Curtobacterium flaccumfaciens pv. flaccumfaciens (Trials 1 and 2)

\begin{tabular}{|c|c|c|c|c|}
\hline Genotype & Trial 1 AUDPC & Trial 2 AUDPC & Mean AUDPC & Reaction \\
\hline IAC Diplomata & $32.08 \mathrm{~d}$ & $38.25 \mathrm{~d}$ & 35.17 & $\mathrm{R}$ \\
\hline P $5-4-4-1$ & $35.28 \mathrm{~d}$ & $35.50 \mathrm{~d}$ & 35.39 & $\mathrm{R}$ \\
\hline C $4-5-4-1-2$ & $37.32 \mathrm{~d}$ & $68.80 \mathrm{c}$ & 53.06 & $\mathrm{R}$ \\
\hline IAC CariocaAkytã & $39.98 \mathrm{~d}$ & $52.22 \mathrm{~d}$ & 46.10 & $\mathrm{R}$ \\
\hline IAC Carioca Pyatã & $45.22 \mathrm{~d}$ & $38.02 \mathrm{~d}$ & 41.62 & $\mathrm{R}$ \\
\hline IAC Imperador & $74.75 \mathrm{c}$ & $94.92 \mathrm{c}$ & 84.84 & $\mathrm{R}$ \\
\hline C $4-8-1-1$ & $100.64 \mathrm{c}$ & $144.45 \mathrm{~b}$ & 122.55 & $\mathrm{~S}$ \\
\hline IAC Carioca Tybatã & $133.28 \mathrm{~b}$ & $44.15 \mathrm{~d}$ & 88.72 & MR \\
\hline IAC Una & $159.84 \mathrm{a}$ & $169.37 \mathrm{a}$ & 164.61 & $\mathrm{~S}$ \\
\hline PR $11-6-4-1-2$ & $165.08 \mathrm{a}$ & $144.57 \mathrm{~b}$ & 154.83 & $\mathrm{~S}$ \\
\hline IAC Harmonia & $169.76 \mathrm{a}$ & $182.87 \mathrm{a}$ & 176.32 & $\mathrm{~S}$ \\
\hline C $2-3-1-1-2$ & $179.66 \mathrm{a}$ & $176.75 \mathrm{a}$ & 178.21 & $\mathrm{~S}$ \\
\hline C $2-1-6-1$ & $182.58 \mathrm{a}$ & $163.85 \mathrm{a}$ & 173.22 & $\mathrm{~S}$ \\
\hline PR $14-2-3-2$ & $183.18 \mathrm{a}$ & $180.05 \mathrm{a}$ & 181.62 & $\mathrm{~S}$ \\
\hline PR $11-3-5-1$ & $183.75 \mathrm{a}$ & $170.92 \mathrm{a}$ & 177.34 & $\mathrm{~S}$ \\
\hline Pérola (uninoculated) & 0 & 0 & 0 & - \\
\hline CV (\%) & 13.86 & 23.3 & & \\
\hline
\end{tabular}

Means followed by the same letters in a column do not differ by the Scott-Knott test $(\mathrm{p}<0.05)$. 
Comissão 2012). These results are consistent with those of our study for IAC Carioca Aruã, IAC Carioca Akytã, IAC Carioca Pyatã, IAC Carioca Tybatã, and IAPAR 31 (Tables 1, 2 and 3). In addition, the cultivars IAC Diplomata, IAC Alvorada, IAC Imperador, IPR Corujinha, IPR Tangará, IAPAR Siriri, BRS Valente and the lines P 5-4-4-1, and C $4-5-4-1-2$ also stood out with high or moderate
Cff-resistance levels (Tables 1 and 2), which are so far not described in the literature.

The resistance observed in the cultivars IAC Alvorada and IAC Diplomata was probably inherited from IAC Carioca Pyatã, which is one of their parents (Carbonell et al. 2008), known for its good levels of Cff-resistance (Maringoni 2002, Camara et al. 2009, Valentini et al. 2011b). The cul-

Table 2. Determination of the area under the disease progress curve (AUDPC) and reaction of common bean genotypes to Curtobacterium flaccumfaciens pv. flaccumfaciens (Trials 3 and 4)

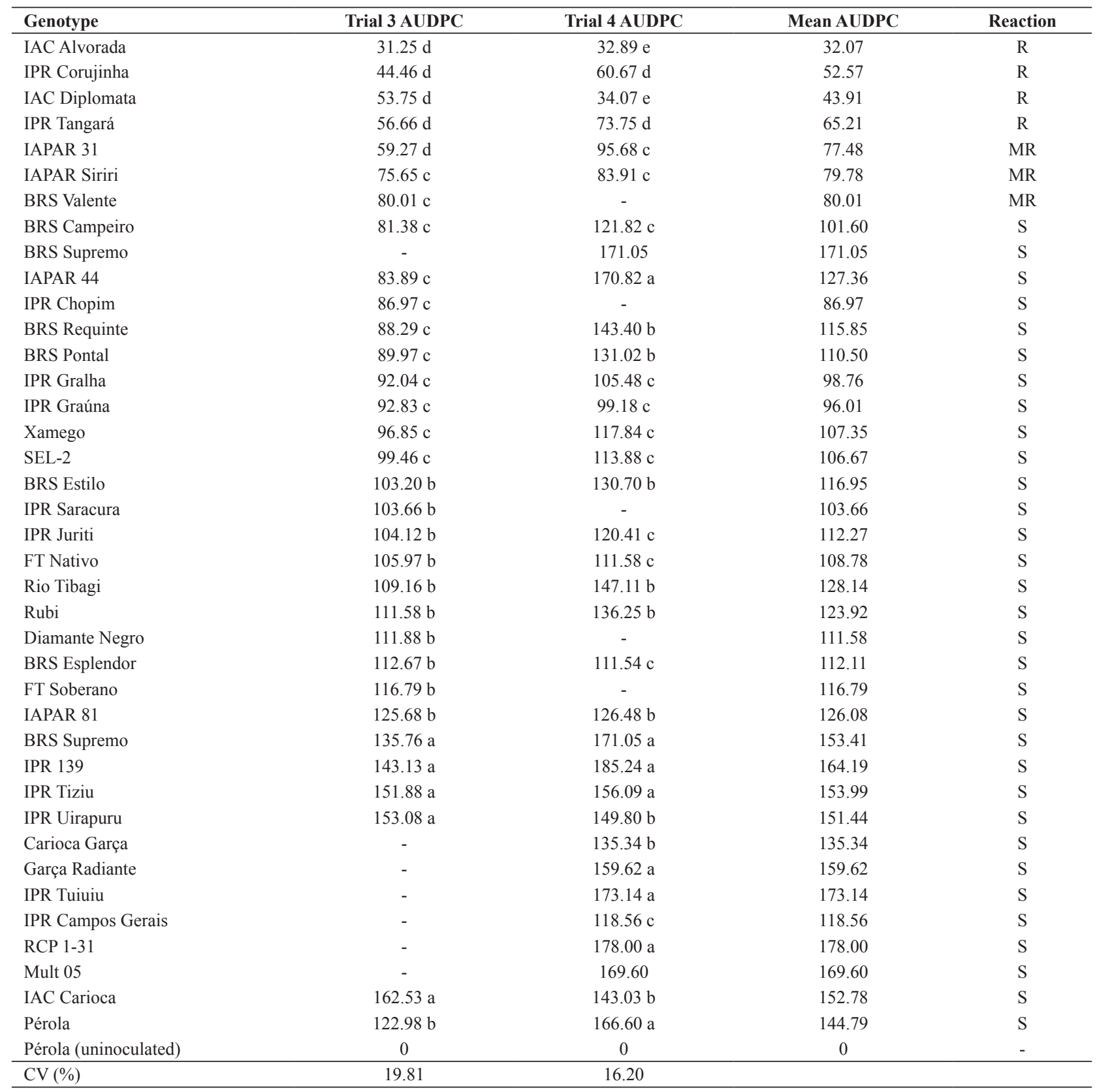

Means followed by the same letters in a column do not differ by the Scott-Knott test $(\mathrm{p}<0.05)$. 
tivars IPR Corujinha, IPR Tangará, and IAPAR Siriri were described as moderately Cff-resistant (Comissão 2012), in partial agreement with our results, since the cultivars IPR Corujinha and IPR Tangará were considered resistant in this study, while IAPAR Siriri was considered moderately resistant (Table 2).

The susceptibility reaction observed in the cultivars IPR 139, IAPAR 81, IPR Uirapuru and IPR Tiziu (Table 2) wasas reported by the Comissão (2012). However, in the cultivars IPR Juriti, IPR Graúna, IPR Saracura, IPR Chopim, and IPR Gralha, whose resistance levels were described as good (Comissão 2012), susceptibility was observed in this study (Table 2). This variation in the behavior of these cultivars may be due to differences in aggressiveness between Cff isolates (Rava et al., 2006), or to other factors that may influence the expression of resistance or susceptibility (Bergamin Filho et al. 1984, Rava et al. 2006, Krause et al. 2009, Morais et al. 2012).

The test results of the colonization of the petiole bases of leaves of common bean cultivars by Cff showed differences in the speed of colonization, depending on the resistance level (Table 3). The bacterium was isolated from fragments of the petiole bases of leaves of the cultivars IAC Carioca, Pérola and IAC Carioca Tybatã at the three sampling times $(5,15$ and 25 DAI). In cultivar IAC Carioca Pyatã, Cff was detected at the base of the primary leaf petiole ( 5 and $15 \mathrm{DAI}$ ), the petiole bases of the first and second trifoliate leaves (15 and $25 \mathrm{DAI}$ ) and was not detected at the petiole base of the third trifoliate leaf (25 DAI) (Table 3). In the cultivar IAC Carioca Diplomata, Cff was detected at the petiole base of the primary ( 5 and $15 \mathrm{DAI})$ and of the first trifoliate leaves, but on only one plant (5 DAI). In this cultivar, Cff was not detected at the petiole base of the first and second trifoliate leaves (15 DAI), and of the third trifoliate leaf (25 DAI) (Table 3).

This difference in the colonization speed of plants of Cff-resistant and susceptible cultivars is possibly related to resistance mechanisms that were activated in resistant genotypes, blocking or restricting the colonization of xylem vessels, as pointed out by Souza et al. (2006). The authors studied the xylem vessels in stems of Cff-resistant cultivars and detected the presence of clumps in bacterial cells involved in filament and lace-like structures under marks in the walls of xylem vessels, which blocked the movement of bacteria to other parts of the xylem vessel, away from the point of inoculation. According to Souza and Maringoni (2008), protoplasmic projections are formed towards the inside of

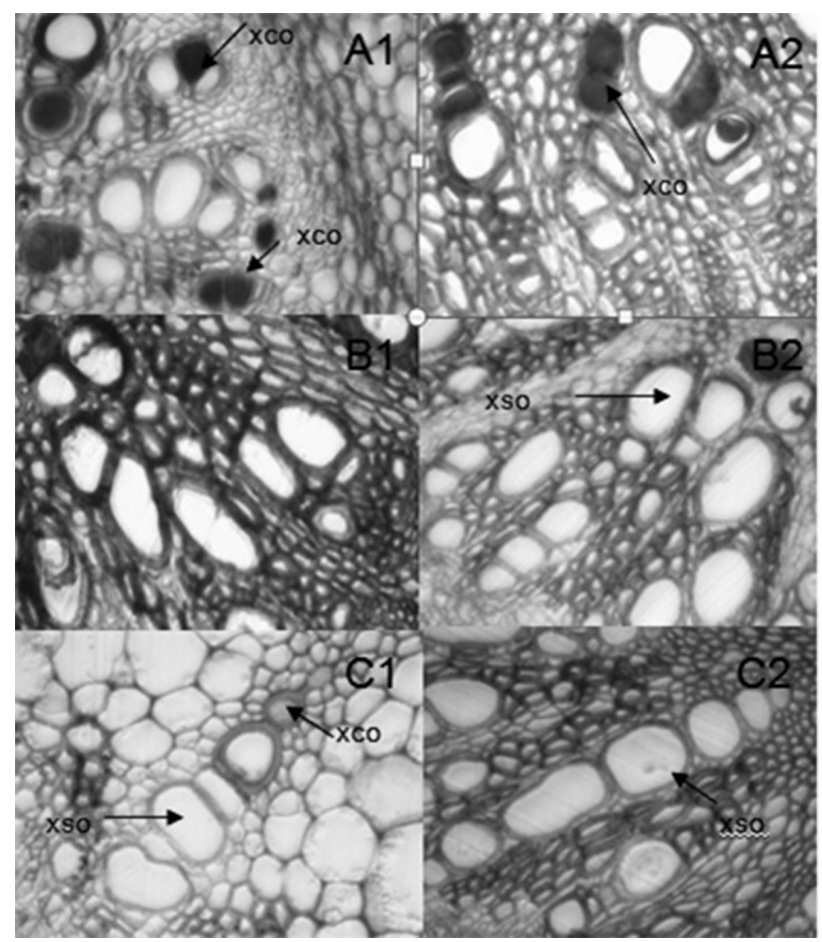

Figure 1. Photomicrograph of xylem vessels at the petiole base of the first (A1, B1, C1) and third (A2, B2 and C2) trifoliate leaves of common bean cultivars IAC Carioca (A1 and A2), IAC Carioca Tybatã (B1 and $\mathrm{B} 2)$ and IAC Diplomata(C1 and $\mathrm{C} 2)$, blocked (XCO) or unobstructed (XSO), 25 days after inoculation with Curtobacterium flaccumfaciens pv. flaccumfaciens.

Table 3. Detection of Curtobacterium flaccumfaciens pv. flaccumfaciens at the petiole base of leaves at different positions on the stem of five common bean cultivars and disease severity 25 days after inoculation (DAI)

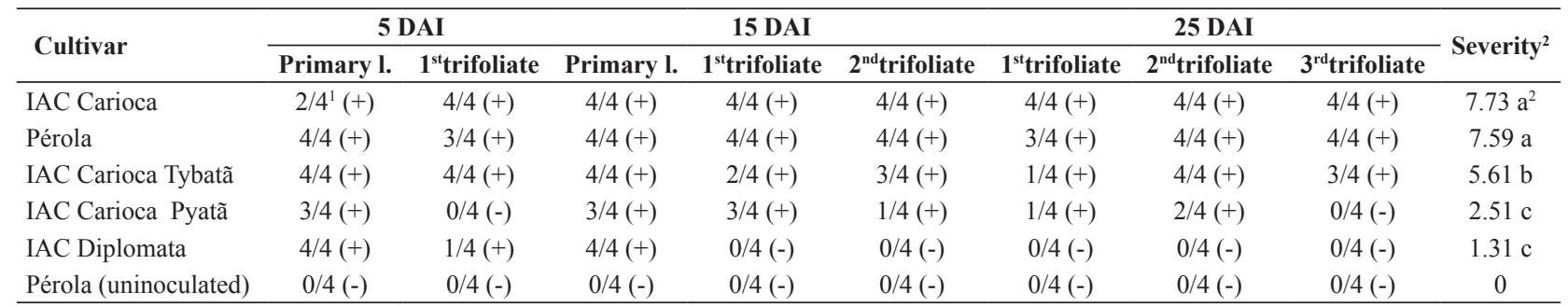

${ }^{1}$ Number of plants with isolation of $\mathrm{Cff}$ at the petiole base of leaf/ Number of plants subjected to isolation

$+=$ Isolation of Cff in semi-selective culture medium;--= Non-isolation of Cff in semi-selective culture medium

${ }^{2}$ Grades $0-9$, means followed by the same letters in a column do not differ by the Scott-Knott test $(\mathrm{p}<0.05)$. 
AC Maringoni et al.

Table 4. Percentage of primary xylem vessels of the petiole base of the first, second and third trifoliate leaf with obstruction in five common bean cultivars, 25 days after inoculation with Curtobacterium flaccumfaciens pv.flaccumfaciens

\begin{tabular}{lccc}
\hline \multirow{2}{*}{ Cultivar } & \multicolumn{2}{c}{ \% of blocked xylem vessels } \\
\cline { 2 - 4 } & $\mathbf{1}^{\text {st }}$ trifoliate & $\mathbf{2}^{\text {nd }}$ trifoliate & $14.08 \mathrm{a}$ \\
\hline IAC Carioca & $29.00 \mathrm{a}^{1}$ & $35.88 \mathrm{a}$ & $24.53 \mathrm{a}$ \\
Pérola & $35.58 \mathrm{a}$ & $32.82 \mathrm{a}$ & $6.60 \mathrm{~b}$ \\
IAC Carioca Tybatã & $7.82 \mathrm{~b}$ & $7.03 \mathrm{~b}$ & $2.93 \mathrm{~b}$ \\
IAC Carioca Pyatã & $3.98 \mathrm{~b}$ & $3.03 \mathrm{~b}$ & $0.48 \mathrm{~b}$ \\
IAC Diplomata & $5.93 \mathrm{~b}$ & $1.20 \mathrm{~b}$ & 0 \\
Pérola (uninoculated) & 0 & 0 & 43.48 \\
\hline CV $(\%)$ & 34.92 & 52.00 & \\
\hline
\end{tabular}

${ }^{1}$ The data transformed by arcsine $\sqrt{ } \mathrm{x} / 100$; Means followed by same letters in a column do not differ by the Scott-Knott test $(\mathrm{p}<0.05)$.

xylem vessels in Cff-resistant bean genotypes, indicating the onset of tylose formation and clogging of xylem vessels that restrict bacteria colonization.

In the Cff-susceptible cultivars IAC Carioca and Pérola, a higher amount of primary xylem vessels was obstructed than in cultivars with higher levels of disease resistance (IAC Carioca Tybatã, IAC Carioca Pyatã and IAC Carioca Diplomata) (Table 4). A tendency to higher amounts of blocked vessels on leaves close to the inoculation site on the stem was also observed in the cvs. Pérola, IAC Carioca Tybatã, IAC Carioca Pyatã, and IAC Carioca Diplomata and this characterize the flow of bacteria colonization in the xylem (Table 4). The presence or absence of obstruction of xylem vessels by Cff at the petiole bases of the first and third trifoliate leaves, in the cultivars IAC Carioca, IAC Carioca Tybatã and IAC Diplomata, are shown in Figure 1.

According to Dinesen (1978), in the stems of Cffsusceptible common bean, only primary xylem vessels are colonized, without gum formation, and the wilting symptoms of the plants are due to the rupture of the waterconducting system, followed by decomposition of the xylem vessels. In the cultivars with higher Cff-resistance levels, there are mechanisms that restrict or impair the colonization of xylem vessels, consequently with lower incidence of obstruction than in susceptible cultivars. These observations agree with Queiroz-Vontanet al. (2005), for the pathosystem coffee-Xylella fastidiosa, where smaller amounts of xylem vessels blocked by bacteria were found in species and varieties with higher levels of resistance to the pathogen. Similarly, Kepmoura et al. (1996) reported that in the pathosystem cassava-Xanthomonas axonopodis pv. manihotis fewer xylem vessels are colonized and greater quantities of phenolic compounds accumulated in resistant than in susceptible cultivars.

\section{ACKNOWLEDGEMENTS}

The authors are indebted to the National Council for Scientific and Technological Development (CNPq) for the financial support of this project.

\section{Reação e colonização de genótipos de feijoeiro comum por Curtobacterium flaccumfaciens pv. flaccumfaciens}

Resumo - A murcha-de-curtobacterium é umas principais doenças do feijoeiro e o uso de cultivares com niveis de resistência é fundamental para o manejo adequado da doença. A reação de 54 genótipos de feijoeiro comum a um isolado de Curtobacterium flaccumfaciens $p v$. flaccumfaciens (Cff) foi avaliada, assim como a colonização de cultivares e a obstrução de vasos de xilema primário da base de peciolos de plantas inoculadas foram quantificadas. Ensaios conduzidos em casa-de-vegetação e laboratório evidenciaram resistência nas cultivares IAC Diplomata, IAC Alvorada, IAC Imperador, IPR Corujinha e IPR Tangará e nas linhagens P5-4-4-1 e C4-5-4-1-2. Uma menor velocidade de colonização por Cff também foi evidenciada nas cultivares resistentes (IAC Diplomata, IAC Carioca Tybatã e IAC Carioca Pyatã), assim como uma menor porcentagem de obstrução dos vasos de xilema primários na base de peciolos, em comparação às cultivares suscetiveis (IAC Carioca e Pérola).

Palavras-chave:Murcha-de-curtobacterium, resistência de cultivares, Phaseolusvulgaris, xilema.

\section{REFERENCES}

Agrianual (2013) Anuário da agricultura brasileira. AgraFNP, São Paulo, 480p.

Bergamin Filho A, Menten JOM and Mendes BMJ (1984) Avaliação de resistência a fitopatógenos. Summa Phytopathologica 10: 137-154.

Camara RC, Vigo SC and Maringoni AC (2009) Plant-to-seed transmission of Curtobacterium flaccumfaciens pv. flaccumfaciens in a dry bean cultivar. Journal of Plant Pathology 91: 549-554. 
Campbell CL and Madden LV (1990) Introduction to plant disease epidemiology. John Wiley \& Sons, New York, 728p.

Carbonell SAM, Chiorato AF, Ito MF, Perina EF, Gonçalves JGR, Souza PS, Gallo PB, Ticelli M, Colombo CA and Azevedo Filho JA (2008) IAC-Alvorada and IAC-Diplomata: new common bean cultivars. Crop Breeding and Applied Biotechnology 8: 163-166.

Comissão Técnca Sul-Brasileira de Feijão (2012) Informações técnicas para o cultivo de feijão na Região-Sul brasileira. Epagri, Florianópolis, $157 \mathrm{p}$.

Dinesen G (1978) The movement of Corynebacterium flaccumfaciens in bean plants (Phaseolus vulgaris). International Conference on Plant Pathogenic Bacteria 2: 929-933.

Eppo (2011) Curtobacterium flacumfaciens pv. flaccumfaciens. EPPO Buletin 41: 320-328.

Hedges F (1922) A bacterial wilt of the bean caused by Bacterium flaccumfaciens nov. sp. Science 55: 433-434.

Huang HC, Erickson RS, Balasubramanian PM, Hsieh TF and Conner RL (2009) Resurgence of bacterial wilt of common bean in North America. Canadian Journal of Plant Pathology 31: 290-300.

Kpemoura K, Boher B, Nicole M, Calatayud P and Geiger JP (1996) Cytochemistry of defense responses in cassava infected by Xanthomonas campestris pv. manihotis. Canadian Journal of Microbiology 42: 1131-1143.

Krause W, Rodrigues R and Leal NR (2009) Identificação de fontes de resistência e avaliação de métodos de inoculação de Curtobacterium flaccumfaciens pv. flaccumfaciens em feijão-vagem. Ciência e Agrotecnologia 33: 1901-1907.

Maringoni AC (2002) Comportamento de cultivares de feijoeiro comum à murcha-de-curtobacterium. Fitopatologia Brasileira 27: 157-162.

Maringoni AC, Camara RC and Souza VL (2006) Semi-selective culture medium for Curtobacterium flaccumfaciens pv. flaccumfaciens isolation from bean seeds. Seed Science and Technology 34: 117-124.

Miranda Filho RJ (2006) Perda de produtividade em feijoeiro comum cv. Pérola causada por Curtobacterium flaccumfaciens pv. flaccumfaciens. Dissertação (Mestrado em Fitopatologia) - Universidade de Brasília, Brasília, 79p.
Morais PPP, Toaldo D, Braatz LR, Andrade LRB, Guidolin AF and Coimbra JLM (2012) Seleção precoce em plantas segregantes de feijoeiro para resistência à murcha-de-curtobacterium. Revista Ceres 59: 803-808.

Nelson RR (1978) Genetics of horizontal resistance to plant diseases. Annual Review of Phytopathology 16: 359-378.

Queiroz-Voltan RB, Cabral LP, Fazuoli LC and Paradela Filho O (2005) Avaliação da suscetibilidade a Xylella fastidiosa em diferentes espécies de cafeeiro. Bragantia 64: 615-624.

Rava CA, Costa JGC, Fonseca JR and Salgado AL (2004) New sources of resistance to bacterial wilt identified in dry bean germplasm collection. Crop Breeding and Applied Biotechnology 4: 111-114.

Rava CA, Costa JGC and Zimmermann FJP (2006) Fatores que afetam a reação de plantas de feijoeiro comum a Curtobacterium flaccumfaciens pv. flaccumfaciens. Revista Eletrônica Faculdade Montes Belos 1: 70-78.

Souza VL, Maringoni AC, Carbonell SAM and Ito MF (2006) Resistência genética em genótipos de feijoeiro a Curtobacterium flaccumfaciens pv. flaccumfaciens. Summa Phytopathologica 37: 339-344.

Souza VL and Maringoni AC (2008) Análise ultraestrutural da interação de Curtobacterium flaccumfaciens pv. flaccumfaciens em genótipos de feijoeiro. Summa Phytopathologica 34: 318-320.

Theodoro GF and Maringoni AC (2006) Murcha-de-curtobacterium do feijoeiro no Estado de Santa Catarina e reação de genótipos a Curtobacterium flaccumfaciens pv. flaccumfaciens. Summa Phytopathologica 32: 34-41.

Valentini G, Baldissera JN, Morais PP, Stahelin D, Heiderman JC, Stenger F, Elias HT, Guidolin AF and Coimbra JLM (2011a) Herança da resistência em feijoeiro à murcha causada por Curtobacterium flaccumfaciens pv. flaccumfaciens. Pesquisa Agropecuária Brasileira 46: 1045-1052.

Valentini G, Baldissera JNC, Rocha R, Almeida CB, Heidemann JC, Guidolin AF and Coimbra JLM (2011b) Sources of resistance to Curtobacterium flaccumfaciens pv. flaccumfaciens in common bean accessions. Crop Breeding and Applied Biotechnology 11: 257-262.

Valentini G, Guidolin AFG, Baldissera JNC and Coimbra JLM (2010) Curtobacterium flaccumfaciens pv. flaccumfaciens: etiologia, detecção e medidas de controle. Revista Biotemas 23: 1-8. 